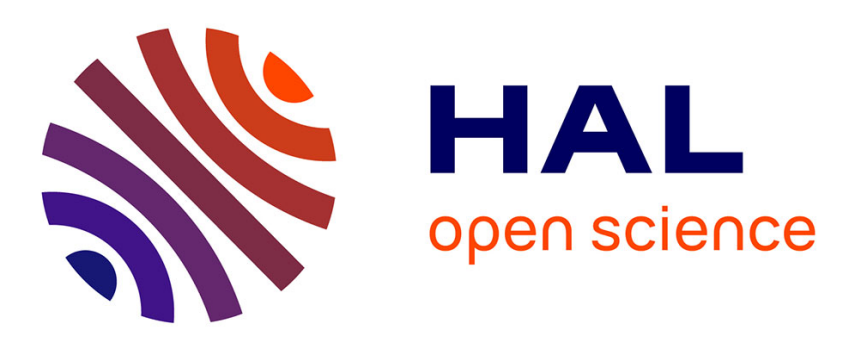

\title{
Daily energy balance and eating behaviour during a 14-day cold weather expedition in Greenland
}

Keyne Charlot, Didier Chapelot, Philippe Colin, Cyprien Bourrilhon

\section{To cite this version:}

Keyne Charlot, Didier Chapelot, Philippe Colin, Cyprien Bourrilhon. Daily energy balance and eating behaviour during a 14-day cold weather expedition in Greenland. Applied Physiology, Nutrition, and Metabolism, 2020, 45 (9), pp.968-977. 10.1139/apnm-2019-0677 . hal-03346261

\section{HAL Id: hal-03346261 \\ https://hal.inrae.fr/hal-03346261}

Submitted on 22 Oct 2021

HAL is a multi-disciplinary open access archive for the deposit and dissemination of scientific research documents, whether they are published or not. The documents may come from teaching and research institutions in France or abroad, or from public or private research centers.
L'archive ouverte pluridisciplinaire HAL, est destinée au dépôt et à la diffusion de documents scientifiques de niveau recherche, publiés ou non, émanant des établissements d'enseignement et de recherche français ou étrangers, des laboratoires publics ou privés. 


\section{Applied Physiology, Nutrition, and Metal}

\section{Daily energy balance and eating behaviour during a 14-day cold weather expedition in Greenland}

\begin{tabular}{|c|c|}
\hline Journal: & Applied Physiology, Nutrition, and Metabolism \\
\hline Manuscript ID & apnm-2019-0677.R2 \\
\hline Manuscript Type: & Article \\
\hline $\begin{array}{r}\text { Date Submitted by the } \\
\text { Author: }\end{array}$ & $n / a$ \\
\hline Complete List of Authors: & $\begin{array}{l}\text { Charlot, Keyne; Institut de recherche biomedicale des armees, Unité de } \\
\text { Physiologie des Exercices et Activités en Conditions Extrêmes, } \\
\text { Département Environnements Opérationnels; Laboratoire de Biologie de } \\
\text { I'Exercice pour la Performance et la Santé, Laboratoire de Biologie de } \\
\text { I'Exercice pour la Performance et la Santé (LBEPS), UMR UEVE-SSA, } \\
\text { Université Evry-Val d'Essonne, } 23 \text { Boulevard François Mitterrand, } 91000 \\
\text { Évry, France } \\
\text { Chapelot, Didier; Université Paris } 13 \text { UFR de Santé Médecine Biologie } \\
\text { Humaine, Centre de Recherche en Epidémiologie et Statistique, Equipe } \\
\text { de Recherche en Epidémiologie Nutritionnelle (EREN), Inserm (U1153), } \\
\text { Inra (U1125), Cnam, } \\
\text { Colin, Philippe; Institut de recherche biomedicale des armees, Unité de } \\
\text { Physiologie des Exercices et Activités en Conditions Extrêmes, } \\
\text { Département Environnements Opérationnels; Laboratoire de Biologie de } \\
\text { l'Exercice pour la Performance et la Santé , Laboratoire de Biologie de } \\
\text { I'Exercice pour la Performance et la Santé (LBEPS), UMR UEVE-SSA, } \\
\text { Université Evry-Val d'Essonne, } 23 \text { Boulevard François Mitterrand, } 91000 \\
\text { Évry, France } \\
\text { Bourrilhon, Cyprien; Institut de recherche biomedicale des armees, Unité } \\
\text { de Physiologie des Exercices et Activités en Conditions Extrêmes, } \\
\text { Département Environnements Opérationnels; Laboratoire de Biologie de } \\
\text { I'Exercice pour la Performance et la Santé, Laboratoire de Biologie de } \\
\text { I'Exercice pour la Performance et la Santé (LBEPS), UMR UEVE-SSA, } \\
\text { Université Evry-Val d'Essonne, } 23 \text { Boulevard François Mitterrand, } 91000 \\
\text { Évry, France }\end{array}$ \\
\hline $\begin{array}{r}\text { Novelty bullets: points that } \\
\text { summarize the key findings in } \\
\text { the work: }\end{array}$ & $\begin{array}{l}\text { Energy intake increases during the second half of a 14-day expedition in } \\
\text { the cold realized by French soldiers, Energy compensation was likely } \\
\text { facilitated by providing participants with easy-to-eat palatable and } \\
\text { familiar foods in excess., Hunger scores and explicit liking for energy- } \\
\text { dense foods were associated with high energy intakes and low body } \\
\text { mass changes. }\end{array}$ \\
\hline Keyword: & $\begin{array}{l}\text { energy intake, energy expenditure, arctic, raid, explicit liking, food } \\
\text { preferences, FPQ-S16, military, rations }\end{array}$ \\
\hline $\begin{array}{l}\text { Is the invited manuscript for } \\
\text { consideration in a Special } \\
\text { Issue? }\end{array}$ & Not applicable (regular submission) \\
\hline
\end{tabular}




\section{SCHOLARONE ${ }^{\text {m }}$ \\ Manuscripts}




\section{Daily energy balance and eating behaviour during a 14-day cold weather expedition in}

\section{Greenland}

Keyne Charlot ${ }^{1,2 *}$, Didier Chapelot ${ }^{3}$, Philippe Colin $^{1,2}$, and Cyprien Bourrilhon ${ }^{1,2}$

${ }^{1}$ Institut de Recherche Biomédicale des Armées, Unité de Physiologie des Exercices et Activités en Conditions Extrêmes, Département Environnements Opérationnels, 1 place Général Valérie André 91223 Bretigny-Sur-Orge, France

${ }^{2}$ Laboratoire de Biologie de l'Exercice pour la Performance et la Santé (LBEPS), UMR UEVE-SSA, Université Evry-Val d'Essonne, 23 Boulevard François Mitterrand, 91000 Évry, France

${ }^{3}$ Université Paris 13, Centre de Recherche en Epidémiologie et Statistique, Equipe de Recherche en Epidémiologie Nutritionnelle (EREN), Inserm (U1153), Inra (U1125), Cnam, Bobigny, France.

\section{Corresponding author}

Keyne Charlot, Phone: +33(1)78651303 ; Fax: +33(1)78651643 ; keynecharlot@gmail.com

\section{Other authors}

Didier Chapelot, Phone: +33(1)48387736 ; Fax: +33(1)48388864 ; chapelot@univ-paris13.fr

Philippe Colin, Phone: +33(1)78651844 ; Fax: +33(1)78651643 ;

philippe4.colin@intradef.gouv.fr

Cyprien Bourrilhon, cyprien1.bourrilhon@intradef.gouv.fr 


\section{Abstract}

We assessed energy compensation, appetite and reward value of foods during a 14-day military expedition in Greenland realized by 12 male French soldiers during which energy compensation was optimized by providing them with easy-to-eat palatable foods in excess. Although daily energy expenditure (estimated by accelerometry) stayed relatively constant

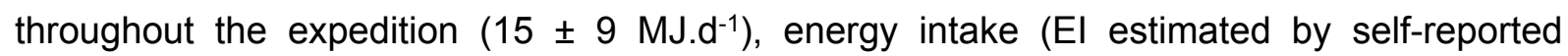
diaries) was $17 \%$ higher during the D8-D14 than D1-D7 period, leading to a neutral energy balance $(E B)$. Body fat mass $(B F M)$ significantly decreased $(-1.0 \pm 0.7 \mathrm{~kg}, p<0.001)$ but not body mass (BM). Neither hunger scores (assessed by visual analog scales), nor components of the reward value of food (explicit liking [EL] and food preference) were significantly altered. However, changes in EL at D10 positively correlated with changes in $\mathrm{BM}(r=0.600, p<0.05)$ and BFM $(r=0.680, p<0.05)$ and changes in hunger with the $\mathrm{El}$ of the relevant period $(r=0.743, p<0.01$ for D1-D7, $r=0.652, p<0.05$ for D8-14). This study shows that the negative EB and BM loss can be attenuated by an appropriate food supply and that subjective components of eating behaviour, such as hunger and EL, may be useful to predict the magnitude of energy compensation.

Keywords: energy intake, energy expenditure, arctic, raid, explicit liking, food preferences, FPQ-S 16 , military, rations 


\section{Résumé}

La compensation énergétique, l'appétit et la valeur de récompense de la nourriture ont été évalués pendant une expédition militaire de 14 jours au Groenland réalisée par 12 soldats français. Bien que la dépense énergétique était relativement stable pendant l'expédition $\left(15 \pm 9 \mathrm{MJ} . j^{-1}\right)$, la prise énergétique (PE) était plus élevée de 17\% pendant la période J8-J14 que la période $\mathrm{J} 1-\mathrm{J} 7$, conduisant à une balance énergétique (BE) neutre. La masse grasse (MG) a significativement diminué $(-1.0 \pm 0.7 \mathrm{~kg}, \mathrm{p}<0.001)$ mais pas la masse corporelle $(M C)$. Ni les scores de faim (évaluées par échelles analogiques visuelles), ni les composantes de la valeur de récompense de la nourriture (explicit liking [EL] et préférence alimentaire) étaient significativement modifiés. Cependant, des modifications d'EL à J10 étaient positivement corrélés avec des modifications de MC $(r=0.600, p<0.05)$ et de MGC $(r=0.680, p<0.05)$ et des modifications de scores de faim avec la PE de la période correspondante $(r=0.743$, $\mathrm{p}<0.01$ pour J1-J7, $r=0.652, p<0.05$ pour J8-J14). Cette étude montre que la BE négative et la perte de MC peuvent être atténuées par l'approvisionnement de nourriture adaptée et que les composantes subjectives du comportement alimentaire, telles que les scores de faim et l'EL, peuvent être utiles pour prédire l'amplitude de la compensation énergétique.

Mots-clef: prise énergétique, dépense énergétique, arctique, raid, explicit liking, préférences alimentaires, FPQ-S ${ }_{16}$, militaires, rations 


\section{Introduction}

Training or expeditions in cold environments (from 3 to 33 days) are generally associated with decreased body mass (BM) (Campbell 1981, Morgan et al. 1988, Edwards and Roberts 1991, Edwards et al. 1992, Jones et al. 1993, King et al. 1993, Hoyt et al. 2001, Johnson et al. 2017, Karl et al. 2017, Beals et al. 2019). This is mostly due to the loss of body fat mass (BFM) (Kyrolainen et al. 2008, Tassone and Baker 2017), despite the availability of excess food. Thus, the increase in energy expenditure (EE) is not adequately compensated by energy intake (EI) (Johnson et al. 2017, Beals et al. 2019). This inability to maintain energy balance (EB) is likely to alter physical (Murphy et al. 2018, Church et al. 2019) and cognitive performance (Cherif et al. 2016), and also mood (Karl et al. 2015), potentially jeopardizing the success of the mission/expedition (Organization. 2010, Day et al. 2012). Even the incorporation of supplemental food packs only partially improves the energy deficit (Edwards and Roberts 1991, Margolis et al. 2016, Karl et al. 2017). Thus, certain mechanisms to match El and EE do not operate when performing a high level of physical activity (PA) in cold weather. The contribution of cold to this phenomenon is unclear. Observational studies conducted in athletes and soldiers, both populations that face frequent and regular periods of high levels of PA-induced EE, show that the EB is regularly negative, even at neutral temperatures (Loucks 2004, Tharion et al. 2005, Richmond et al. 2014, McAdam et al. 2018). This suggests that above a certain threshold of PA, spontaneous El fails to match EE. Over time, decreased EE due to BM loss and a spontaneous increase in El reduces the magnitude of this negative EB. Indeed, modeling of energy compensation during exercise (Riou et al. 2015) shows that El may progressively increase over the first weeks and eventually reach a plateau.

In the short-term, cold has been shown to be an orexigenic environmental strain (White et al. 2005, Wasse et al. 2013, Crabtree and Blannin 2015, Charlot et al. 2017, Mandic et al. 2019). Therefore, the negative EB is expected to be less in cold than hot weather. Indeed, Johnson and colleagues (Johnson et al. 2017) reported 36\% greater El during a 4 to 5-day 
Special Operations Forces field training exercise in cold as compared to hot and warm weather, although EE $\left(\sim 4,500 \mathrm{kcal}^{\left.-\mathrm{d}^{-1}\right)}\right.$ and the amount of available food were similar for both conditions. However, these studies only reported mean El and EE and not their day-to-day variation. Furthermore, the modalities of such a negative EB were not assessed, notably important features of eating behaviour, such as appetite and hedonic factors, the latter often being associated with the reward value of foods. They may provide useful information, as they are strongly involved in the physiology of energy homeostasis (Chapelot and Charlot 2019) and may partially explain why humans fail to increase El and maintain EB in a sustained cold environment. A classic model is that proposed by Kent Berridge and based on the wanting and liking paradigm (Berridge 1996). Explicit liking (EL), implicit wanting (IW), and food preferences (FP) have even been proposed to discriminate between individuals who compensate for the increase in EE and those who do not (Finlayson et al. 2009, Finlayson et al. 2011, Buckland et al. 2019).

The aim of this study was to investigate the various dimensions of eating behaviour of this "loose coupling of daily EE and El" (Drenowatz 2015) during a 14-day cold weather expedition in Greenland performed by French soldiers. We assessed daily EI, EE, appetite, and the reward value of food. Based on the available scientific evidence, we hypothesized that 1) El would progressively increase to reach EB by the end of the expedition, 2) appetite and reward levels would be consistently associated with this increase in El, and 3) increased appetite and reward levels would be higher in individuals who were the less inclined to lose BM. 


\section{Methods}

Design

French soldiers planned this expedition in Greenland as part of an extreme cold inoculation program. They travelled from the north of Liverpool Land in Greenland to the city of Ittoqqortoomiit in the south. The journey lasted two weeks. They skied most of the time but sometimes had to walk with snowshoes. They brought food for 21 days that they towed with a pulka, along with all their materials. In a paper notebook, they were requested to 1) evaluate their appetite in the morning before breakfast and in the evening before dinner, 2) report all food and beverages consumed during the day, and 3) assess the reward value of foods just before dinner on the day prior to the expedition (D0) and the first (D1) and tenth days (D10) of the expedition. Each participant wore a wrist actigraph to estimate EE. Finally, BM and body composition were measured before breakfast on the morning before D0 (D-1) and the day following their arrival (D15).

\section{Participants}

The participants were 12 young males specialized in mountain environment activities (skiing, climbing, and snowshoeing) and extreme conditions (cold and altitude). They were briefed several months before leaving France and were informed of the benefits and risks of the investigation prior to giving their written consent, in accordance with the Declaration of Helsinki. This study was performed at the request of the Armée de Terre and approved by the scientific leadership of the French Armed Forces Biomedical Research Institute. All participants were screened by military physicians and required to be healthy. Maximal oxygen uptake $\left(\mathrm{VO}_{2 \max }\right)$ was estimated using their last Cooper 12-min run test performance (Cooper 1968) based on correlation coefficients between 0.897 and 0.920 (Cooper 1968, Grant et al. 1995). Their individual and mean main characteristics are shown in Table 1.

\section{Measurements}


Body mass and composition

On the morning before leaving for Greenland (D0), the participants had their BM and body composition assessed at a hotel in Reykjavik (Iceland). The measurements were performed before breakfast, with an empty bladder. Their BM was measured to the nearest $0.1 \mathrm{~kg}$ using a calibrated scale (Seca 877, Hambourg, Germany), with participants wearing only their underwear. Absolute and relative BFM were estimated using skinfold thickness values according to the Durnin \& Womersley method and standard equations (Durnin and Womersley 1974). In brief, skinfolds were measured on the right side of the body using a Harpenden skinfold caliper (British Indicators, West Sussex, UK) to the nearest millimeter in triplicate at the four recommended sites: biceps, triceps, and the subscapular, and suprailiac regions. All measurements were performed by the same investigator, under the same conditions, and at the same location, on the day following the end of the expedition to improve reproducibility.

\section{Energy intake}

Before the expedition, each participant packed 21 bags, each containing all the food products necessary for their daily intake. The composition of the diet was similar in energy content and food items for all bags. It was primarily based on the participants' eating habits during prior similar expeditions and consisted of lyophilized muesli and cakes for breakfast; energy bars, chocolate bars, jerky meat, soup, dried cheese, flat bread, candies, and cakes for the day while moving; and lyophilized dishes and dessert for dinner. Each bag provided approximately $19 \mathrm{MJ}(4,500 \mathrm{kcal})$ and participants were allowed to bring a supplementary bag containing ready-to-eat foods (essentially bars) and to consume some or all of it if they felt hungry or the need to. At the end of each day, prior to sleep, they had to complete a form on which they accurately reported which foods they had consumed from the daily and supplementary bags. The daily energy and macronutrient intakes of each participant were then calculated using the nutritional composition of the foods provided by the manufacturers. 
Participants were outfitted with a wrist-worn tri-axial actigraph (MotionWatch 8, CamNTech, Papworth Everard, UK) on the non-dominant arm to assess daily EE. This technology has been found to be reliable for assessing EE during activities under 6 METs (Sirichana et al. 2017) and showed good reliability in assessing physical activity, albeit this was assessed in older adults only (Landry et al. 2015, Chakravarthy and Resnick 2017). The highest intensity during the expedition was estimated to be approximately 6 METs. This specific device is designed to record accelerations ranging in magnitude from $0.01 \mathrm{G}$ to $8 \mathrm{G}$ with a frequency of $3-11 \mathrm{~Hz}$. It is equipped with a filter that removes artifacts from movements with frequencies higher than the typical range of human movements (vibration or tremor). Data were recorded using 60-s epochs, as recommended (Ward et al. 2005). The time spent in each class of physical activities was determined using the device software (MotionWare 1.0.27, CamNTech, Papworth Everard, UK): sedentary activities (< $1.5 \mathrm{MET}$ ), light activities (between 1.5 and 3.0 METs), moderate activities (between 3.0 and 4.5 METs), and vigorous activities (> 4.5 METs). After calculating the resting metabolic rate (RMR; i.e. 1 MET) using the Mifflin-St Jeor equation (Mifflin et al. 1990), the daily EE was then estimated using the following formula

Where $t$ is the time in seconds associated with $1,2.25,3.75$, and 5 METs for sedentary (SED), light (LIGHT), moderate (MOD), and vigorous (VIG) activities, respectively.

Energy balance was then calculated by subtracting EE from El.

Appetite was assessed by rating hunger on visual analog scales (VAS). The participant had do you feel?" and anchored at the left and right ends by "not at all" and "extremely", 
respectively. The distance from the extreme left to the participant's vertical dash represented the rating score, expressed in $\mathrm{cm}$. Participants were asked to rate these VAS over the last two weeks prior to the expedition and familiarize themselves with the material and the appetite scales.

\section{Reward value of food}

Several years ago, Finlayson et al. (Finlayson et al. 2007, Finlayson et al. 2008) developed the Leeds Food Preference Questionnaire (LFPQ). This questionnaire measures several components of food reward, i.e., EL, IW, and FP (Dalton and Finlayson 2014). We recently validated a shorter version of this questionnaire, called the Food Preference Questionnaire (FPQ-S 16 ), using 16 food items and adapted to the French context (Charlot et al. 2018). This version was found to be reliable, with correlation coefficients between 0.83 and 0.88 , and less time-consuming, but only assesses EL and FP by choice-reaction time. Given the difficulties of using a computer during the expedition, such as the weight of the equipment and the very low temperatures, the $\mathrm{FPQ}-\mathrm{S}_{16}$ was adapted to paper. Briefly, the questionnaire is composed of 16 pictures of food items categorized according to their fat content (high-fat $[\mathrm{HF}]$ or low-fat [LF]) and taste (sweet [SW] or savory [SA]). This results in four specific food categories (HF, LF, SW, and SA) with eight food items in each, and four combined categories (HFSW, HFSA, LFSW, and LFSA) with four food items in each. First, to assess EL, participants had to answer the question "How pleasant would it be to taste some of this food now?" for each food on a VAS. Then, to assess FP, the 16 food items were presented on the same page in a randomized order. Participants were asked to rank these items in four groups, ranging from the one that contained the four food items that they "wanted to eat the most now" $(++)$, to the one that contained the four food items that they "wanted to eat the least now" (--). The number of food items from a specific (HF, LF, SW, or SA) or combined (HFSW, HFSA, LFSW, or LFSA) category was multiplied by the group coefficient ( 3 for,++ 2 for,+ 1 for -, and 0 for --) and then the scores from each group added. The score ranges for the specific ( 8 food items) and combined ( 4 food items) categories are therefore 4 to 20 and 
2120 to 12, respectively. Absolute scores were used to assess EL and bias scores were 213 calculated for FP by subtracting a score from each category with its opposite one (e.g., HF vs 214 LF or HFSA vs LFSA). Thus, a positive or negative score indicates a preference for one 215 category over the other. This procedure was conducted in a hungry state prior to dinner, just 216 before the beginning of the expedition (D0), just after (D1), and 10 days later (D10). As the 217 expedition was expected to last 21 days, we planned the FPQ-S ${ }_{16}$ at the midpoint (D10) and 218 end of the expedition (D20). However, it was shortened to 14 days (see part 3.1.) and the 219 D20 measurement was not performed.

Statistical analyses

221 Given the highly variable conditions of such expeditions, e.g., weather and distance travelled per day (see part 3.1 for details), we divided the temporal analysis into two periods: D1-7 and D8-14. Indeed, comparing day-to-day differences would have required highly conservative corrections for multiple comparisons and would have been subjected to artifacts due to certain single-day events. After ensuring that the data were normally distributed using a Shapiro-Wilk test, Student's $t$-tests were used for all outcomes, except EL and FP. EL and FP were compared using a single mixed-model repeated-measures $3 \times 1$ ANOVA with day (D0, D1, and D10) as the within-subject factor. Correlations between variables were tested using Pearson correlation coefficients. Data are presented as the means \pm SD. Significance was defined as $p<0.05$. Analyses were performed using STATISTICA software ( 10 , Statsoft, Tulsa, OK, USA). 


\section{Results}

233

234

235

236

237

238

239

Details of the expedition

Meteorological conditions faced between D2 and D4 caused a modification of the initially planned route. Indeed, a windstorm (maximal wind speed recorded $180 \mathrm{~km} \cdot \mathrm{h}^{-1}$ ) prevented the participants from leaving their tents on D3 and D4 and caused major material damage (mostly tent tears). The need to make repairs forced the soldiers to modify their itinerary and to reach a shelter. The remainder of the expedition was therefore shortened by the expedition chief. The details of the route are shown in Figure 1. They remained in the same locations for a total of five days (D3 and D4: facing the windstorm, D6: repairing the equipment, D10: climbing near the base, and D14: waiting for jet skis to the reach airport). They travelled $123 \mathrm{~km}$ (56 and $67 \mathrm{~km}$ in the first and second halves of the expedition, respectively) for a mean daily distance of $8.79 \mathrm{~km}$ with $+312 \mathrm{~m}$ and $-318 \mathrm{~m}$. The weather became less windy and colder as the expedition progressed. Mean temperatures (relative humidity) were $-8.7^{\circ} \mathrm{C}(77.5 \%)$ during the first half and $-13.4^{\circ} \mathrm{C}(68.6 \%)$ during the second half of the expedition, with mean wind speeds of 32.7 and $14.7 \mathrm{~km} \cdot \mathrm{h}^{-1}$, respectively.

\section{Energy intake and expenditure}

Individual and mean EI, EE, and EB are shown in Figure 2. Time spent for sedentary, light, moderate, and vigorous activities were $888 \pm 37,176 \pm 31,111 \pm 14$, and $265 \pm 38 \mathrm{~min}^{-\mathrm{d}^{-1}}$, respectively. There was a statistically significant period effect for $\mathrm{EI}(p=0.007)$ and $\mathrm{EB}(p=$

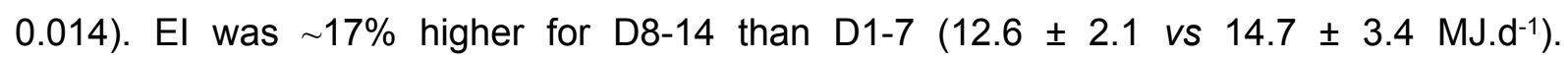

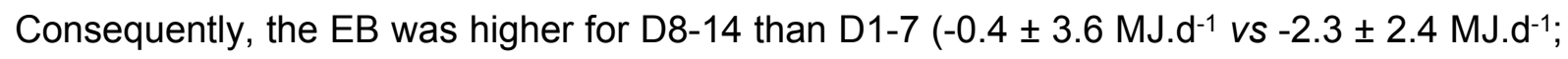
$p=0.014)$. The difference between El and EE was only significant in the first half of the expedition ( $\mathrm{D} 1-7 ; p=0.007)$, indicating that the participants were in negative $E B$ during this period and in neutral EB during the second one. 
Absolute and relative macronutrient intake is shown in Table 2. We observed a period effect for all absolute macronutrients $(p=0.005,0.017$, and 0.003 for $\mathrm{CHO}$, fat, and protein, respectively), which was $\sim 15,14$, and 16\% higher, respectively, for D8-14 than D1-7.

\section{Body mass and composition}

260

261

262

263

264

265

266

267

Individual and mean changes in BM and body composition between the beginning and end of the expedition are shown in Figures $3 \mathrm{~A}$ and $3 \mathrm{~B}$. Body mass was $76.1 \pm 6.8$ before and $75.0 \pm$ $6.3 \mathrm{~kg}$ after the expedition, the difference $(-1.1 \pm 1.8 \mathrm{~kg},-1.3 \pm 2.2 \%)$ failing to reach statistical significance $(p=0.091)$. BFM and body fat-free mass $(B F F M)$ were $15.8 \pm 2.4$ and $60.3 \pm 6.0 \mathrm{~kg}$, respectively, before the expedition and $14.8 \pm 2.6$ and $60.2 \pm 5.8 \mathrm{~kg}$, respectively, after the expedition. The change in BFM was significant $(-1.0 \pm 0.7 \mathrm{~kg},-6.4 \pm$ $4.7 \%, p<0.001)$ but not the change in BFFM $(-0.1 \pm 1.5 \mathrm{~kg},-0.1 \pm 2.4 \%)$.

Individual changes in $\mathrm{BM}$ and $\mathrm{EB}$ are presented in Figure $3 \mathrm{C}$, showing that there was a wide variation and a continuum of responses to the expedition-induced increase in EE. These two variables positively correlated with each other $(r=0.702, p=0.011)$, indicating that the larger the energy deficit, the larger the loss of BM.

\section{Appetite}

ANOVA revealed no time effect for the morning and evening measurements of the hunger scores (Figure 4).

\section{Explicit liking and food preference}

The absolute scores (EL) for each specific and combined category and bias scores (FP) between specific and combined categories are shown in Table 3. ANOVA revealed no effect of the day for EL or FP, suggesting that the expedition did not alter the mean reward value of food.

\section{Correlations}


280 Meaningful correlations between all the variables measured in this study are shown in Table 281 4. First, changes in BM (in \%) were positively associated with $\mathrm{El}, \mathrm{EB}$, absolute fat and protein 282 intake, and relative fat intake, and negatively associated with relative $\mathrm{CHO}$ intake. Then, they 283 were also positively associated with the EL score of the HFSW food items, but only at D10. 284 Second, changes in BFM (in \%) were positively associated with the EL scores of HF foods at 285 D1 and D10, but not D0. Finally, the mean total El was positively associated with mean total 286 hunger scores; this correlation was also significant between these variables during both 287 halves of the expedition i.e., El with hunger on D1-7 and El with hunger on D8-14. 


\section{Discussion}

289

290

291

292

293

294

295

296

297

298

299

300

301

302

303

304

305

306

307

One of the main differences between this expedition and others featuring in studies

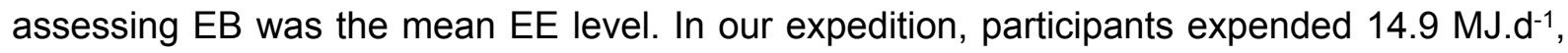

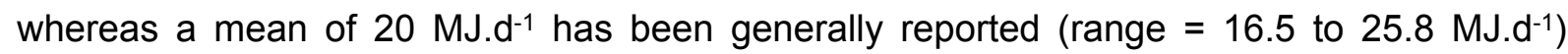
(Morgan et al. 1988, Edwards and Roberts 1991, Edwards et al. 1992, Jones et al. 1993, King et al. 1993, Margolis et al. 2016). This is likely the result of differences in activities and their duration, objectives, and environment. The variety of activities was wider in the other expeditions than this one, notably including highly demanding specific military tasks. For example, some programs required "establishing a defensive position, constructing defensive obstacles, and erecting camouflage tents" (Edwards et al. 1992), survival tasks ("compass training, ice fishing, and hunting" (Jones et al. 1993), "avalanche avoidance and rescue and night land navigation" (Morgan et al. 1988)), or sports activities (6 km ski race and 10-km biathlon (Morgan et al. 1988)). Moreover, the duration of these activities was longer (5-13 h.d-1 (Jones et al. 1993) vs $\sim 5$ h.d $^{-1}$ in the present study), with shorter sleep periods (4-6 h.d${ }^{1}$ (Edwards and Roberts 1991, Edwards et al. 1992) vs 7-8 h.d-1 in the present study). When the activities were similar (only skiing), the objective was higher (51 km in 4 days (Margolis et al. 2016) vs $123 \mathrm{~km}$ in 14 days in the present study). Finally, although environmental temperatures in the present study (between -19 and $-6{ }^{\circ} \mathrm{C}$ ) were in the usual reported range (between -48 and $+12^{\circ} \mathrm{C}$ ) (Morgan et al. 1988, Edwards and Roberts 1991, Edwards et al. 1992, Jones et al. 1993, King et al. 1993), they were not among the harshest.

Despite a relatively low EE, mean El (13.6 MJ.d-1) was in the upper range of similar studies

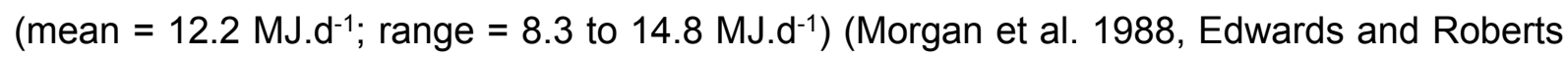
1991, Edwards et al. 1992, Jones et al. 1993, King et al. 1993, Margolis et al. 2016). King et al. (King et al. 1992) stated that the total energy content of the provided rations, their palatability and acceptability, their ease of preparation, and their diversity may influence El in the context of extreme cold. In the present study, the energy value of the rations ( 19 MJ) largely exceeded EE. The selected foods were a mix of lyophilized rations and personal 
items that participants had previously consumed and appreciated, although acceptability was not specifically assessed. Moreover, apart from the lyophilized items that had to be rehydrated, foods were consumable in their natural form. Finally, a supplementary bag of easy-to-eat and highly palatable food items was always available for extra food consumption. Thus, the conditions favored optimal energy compensation. Although a large negative EB

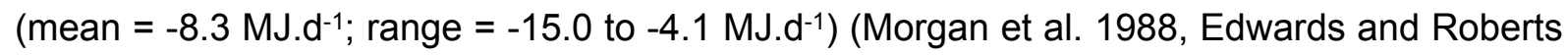
1991, Edwards et al. 1992, Jones et al. 1993, King et al. 1993, Margolis et al. 2016) and BM loss $\left(\right.$ mean $=-0.25 \mathrm{~kg} . \mathrm{d}^{-1} ;$ range $=-0.06$ to $\left.0.72 \mathrm{~kg}^{-\mathrm{d}^{-1}}\right)($ Campbell 1981, Morgan et al. 1988, Edwards and Roberts 1991, Edwards et al. 1992, Jones et al. 1993, King et al. 1993, Hoyt et al. 2001, Johnson et al. 2017, Karl et al. 2017, Beals et al. 2019) seems unavoidable during such an expedition in the cold, the EB was only negative for the first period $\left(-2.3 \pm 2.4{\left.\mathrm{MJ} . \mathrm{d}^{-1}\right)}^{-1}\right.$ and the slight decrease in BM $\left(0.07 \mathrm{~kg}^{-\mathrm{d}^{-1}}\right)$ was not significant.

Long-term sustained high levels of EE are known to lead to equilibrium with El, resulting in the maintenance of a neutral EB and therefore a stable BM (Mayer et al. 1956, Beaulieu et al. 2018). However, the time required to reach this equilibrium is less documented. Whybrow et al. (Whybrow et al. 2008) reported no modification of El in lean men during a 14-day daily

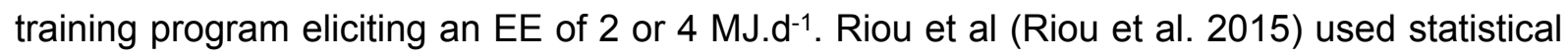
models and observed an increase in the degree of energy compensation during the first 20 weeks of a training program. However, the first four weeks were not considered in the models. The kinetics of El during expeditions (more than 20 days) in mildly cold to hot environments have shown discrepant results, with no modification (Edwards et al. 1992,

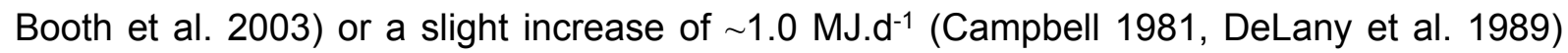
after the first two weeks. Given these scarce results, it is difficult to draw unequivocal conclusions. It must be noted that the aforementioned studies were not designed to assess modifications of El throughout the period of measurements. Nevertheless, these results suggest that energy compensation may require 14 days to be observable. Our results suggest that such compensation may occur more rapidly (from the second week) in a cold 


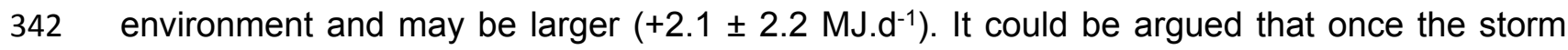
343 was over (after D6), the soldiers would have been able to eat more comfortably, which could partially explain the increase in El in the second period. Further studies are needed to confirm the kinetics of such compensatory behaviour, i.e. when compensation occurs and when it reaches a plateau.

Assessments of $\mathrm{El}$ and $\mathrm{EE}$ during training or expeditions in the cold are most often performed to calculate the mean EB and subsequent changes in BM and body composition (Tassone and Baker 2017). This concern resonates well with the armed forces. Indeed, sustained energy deficit has been shown to lead to decreased physical and cognitive performance, increasing individual and collective risks and therefore jeopardizing the success of an operative mission (Murphy et al. 2018, Church et al. 2019). One objective has sometimes been to assess the efficiency of alternative meals (Morgan et al. 1988, Edwards and Roberts 1991, Edwards et al. 1992, King et al. 1993) or supplemental foods (Edwards and Roberts 1991, Margolis et al. 2016) to improve energy compensation and reach a more neutral EB. However, attempts to better understand the "loose coupling of daily EE and El" (Drenowatz 2015) in identifying the kinetics of various components of eating behaviour are missing. Therefore, we included tools that allowed us to assess two of the most determinant components of eating behaviour, i.e. appetite and preferences. Subjective ratings of appetite (the morning or evening prior to meals) were not altered, suggesting either that El was adequate or that the use of endogenous energy from body stores inhibited the motivation to eat (Chapelot and Charlot 2019). In comparison, hunger scores increased during a four-day arctic military training mission (Margolis et al. 2016). However, the energy deficit was much

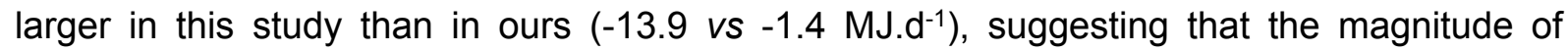
appetite-inhibiting endogenous energy may be limited.

Analyses of the correlations in our study favour a putative role of the reward value of foods and the validity of the paper-version of the $F P Q-S_{16}$, as they revealed several positive interindividual relationships between this hedonic component and objective parameters. First, 
changes in appetite positively correlated with El, showing that, overall, among the participants, the higher their hunger scores, the greater the increase in their El. The fact that these correlations were only significant within the same period (D1-7, D8-14 or D1-14) suggests the validity of this coupling between subjective and objective outcomes of appetite. It must be noted that two recent reviews (Sadoul et al. 2014, Holt et al. 2017) reported that the ability of pre-meal hunger scores to predict El is uneven. Our results suggest that this relationship may improve if mean hunger scores recorded over several days are used. In addition, EL for foods with high energy density (HFSW and HF) positively correlated with changes in BM and BFM. In other words, individuals who attributed a high reward value to HF foods during the expedition were less likely to lose BM or BFM. It was previously observed that individuals who compensated for the energy expended during a single exercise or those who minimally responded to a 12-week training program (i.e. small modifications in body composition) showed a higher preference for HFSW foods than noncompensators (Finlayson et al. 2009) and responders (Finlayson et al. 2011), respectively. Overall, these results suggest that participants who display an "orexigen" profile (increase in appetite, increase in EL for HF foods) during an expedition in the cold may be more inclined to compensate for high levels of EE and maintain their BM and body composition. Such compensation may however have an upper threshold, as authors recently concluded from a compilation of data that the "alimentary limit" (i.e. maximal El) was reached for 2.5 fold the basal metabolic rate (Thurber et al. 2019).

Any experiment under harsh environmental conditions is vulnerable to unexpected contingencies. In this expedition, participants were confronted with a storm on days 3 and 4 that altered the planned route. The main consequence was the impossibility to maintain a constant volume of physical activity over the 14 days of measurements. Another possible consequence was an alteration in food intake. It can be argued that participants voluntarily reduced their intake during the windstorm to spare food. However, they were informed about the storm on day 2 by a weather specialist based in France and knew that it would only last 
396 two days. This is therefore unlikely and, indeed, was not reported by participants after the 397 expedition. The quality of self-reporting or El itself may theoretically be modified by such adverse events. We were unable to evaluate their impact on our results. However, these men were mentally prepared to face the consequences of extreme conditions, such as spending two days in the tents because of the bad weather, repairing material after the storm, or having to change their route. After the expedition, the participants assured us that they did not neglect the completion of their food diaries. Compromises were made to select the most accurate tools that participants agree to use under self-sufficiency conditions and in extreme cold, without jeopardizing the mission. Thus, EE might have been assessed with more accurate methods (e.g. the double labeled water technique (Margolis et al. 2016, Johnson et al. 2017) or individual $H R-V_{2}$ regression (Beals et al. 2019)) and FPQ-S 16 might have been preferentially completed on tablets, as under laboratory conditions, than on paper. Furthermore, it was not possible to infer IW from our data, as no time-reaction could be measured in the FPQ-S 16 and thus this relationship is yet to be established. Then, we acknowledge that the observations presented in the present study concern a specific sample of participants. They were considered to have the fitness level of highly trained/elite athletes based on their usual volume of physical activity and estimated VO2max. In addition, their relatively high levels of BFM relative to their high fitness level suggest that they may have adopted a high-calorie diet during the weeks/months prior to the expedition to increase their energy stores. Body composition assessments well before the expedition to verify this hypothesis are not available. Nonetheless, it is certain that the results obtained with this sample are not generalizable to a broader group. Another limitation is that we did not assess thirst, fluid intake, or hydration status. This is a concern, since an influence of dehydration on various dimensions of eating behaviour has been reported (Engell 1988, Mattes 2010). Moreover, dehydration may alter the accuracy of BFM estimation. The effect of dehydration has led to discrepant results in previous studies, which showed a small increase (Araujo et al. 2018) or decrease (Rodriguez-Sanchez and Galloway 2015) in BFM values. Thus, although some studies conducted under similar conditions suggest that fluid intake is in 
accordance with need (Edwards et al. 1992, King et al. 1993), it is possible that our results may have been somewhat influenced by a certain state of dehydration. Nonetheless, for the first time, several markers of eating behaviour were accurately recorded and further explored how trained individuals adapt to a prolonged period of high EE, coupled with a continuous extreme cold exposure and an abundance of palatable food items at their disposal.

\section{Conclusion}

We observed an increase in El after seven days during a 14-day expedition performed by French soldiers, in agreement with the first hypothesis and suggesting that when eating conditions are optimized with the appropriate amount, quality, and conditioning of foods, total energy compensation may occur more rapidly than that generally described. Eating behaviour components, such as hunger and the reward value of foods, were assessed for the first time, and although they did not change during the expedition, in contradiction to our second hypothesis, correlations show a certain amount of coupling between hunger and EI and between EL for HF foods and body changes. Finally, as stated by the third hypothesis, some of these elite individuals will respond more adequately than others to the energy homeostasis challenge and this difference is detectable by hunger and hedonic factors. 


\section{References}

441

442

443

444

445

446

447

448

449

450

451

452

453

454

455

456

457

458

459

460

461

462

463

464

465

466

Araujo, D., Teixeira, V.H., Carvalho, P. and Amaral, T.F. 2018. Exercise induced dehydration status and skinfold compressibility in athletes: an intervention study. Asia Pac J Clin Nutr 27(1): 189-194 doi: 10.6133/apjcn.022017.20.

Beals, K., Perlsweig, K.A., Haubenstriker, J.E., Lovalekar, M., Beck, C.P., Yount, D.L., et al. 2019. Energy Deficiency During Cold Weather Mountain Training in NSW SEAL Qualification Students. Int J Sport Nutr Exerc Metab 29(3): 315-321 doi: 10.1123/ijsnem.2018-0041.

Beaulieu, K., Hopkins, M., Blundell, J. and Finlayson, G. 2018. Homeostatic and nonhomeostatic appetite control along the spectrum of physical activity levels: An updated perspective. Physiol Behav 192: 23-29 doi: 10.1016/j.physbeh.2017.12.032.

Berridge, K.C. 1996. Food reward: brain substrates of wanting and liking. Neurosci Biobehav $\operatorname{Rev} 20(1): 1-25$

Booth, C., Coad, R. and Roberts, W. 2003. Evaluation of an Australian combat ration pack as a sole nutrition source during 23 days of military adventurous training in the tropics. Nutr Diet 60: 239-247.

Buckland, N.J., Camidge, D., Croden, F., Myers, A., Lavin, J.H., Stubbs, R.J., et al. 2019. Women with a low satiety phenotype show impaired appetite control and greater resistance to weight loss. Br J Nutr: 1-22 doi: 10.1017/S000711451900179X.

Campbell, I.T. 1981. Energy intakes on sledging expeditions. Br J Nutr 45(1): 89-94.

Chakravarthy, A. and Resnick, B. 2017. Reliability and Validity Testing of the MotionWatch 8 in Older Adults. J Nurs Meas 25(3): 549-558 doi: 10.1891/1061-3749.25.3.549.

Chapelot, D. and Charlot, K. 2019. Physiology of energy homeostasis: Models, actors, challenges and the glucoadipostatic loop. Metabolism 92: 11-25 doi: 10.1016/j.metabol.2018.11.012.

Charlot, K., Faure, C. and Antoine-Jonville, S. 2017. Influence of Hot and Cold Environments on the Regulation of Energy Balance Following a Single Exercise Session: A Mini-Review. Nutrients 9(6)doi: 10.3390/nu9060592. 
Charlot, K., Malgoyre, A. and Bourrilhon, C. 2018. Proposition for a shortened version of the Leeds Food Preference Questionnaire (LFPQ). Physiol Behavdoi: 10.1016/j.physbeh.2018.11.022.

Cherif, A., Roelands, B., Meeusen, R. and Chamari, K. 2016. Effects of Intermittent Fasting, Caloric Restriction, and Ramadan Intermittent Fasting on Cognitive Performance at Rest and During Exercise in Adults. Sports Med 46(1): 35-47 doi: 10.1007/s40279-015-0408-6.

Church, D.D., Gwin, J.A., Wolfe, R.R., Pasiakos, S.M. and Ferrando, A.A. 2019. Mitigation of Muscle Loss in Stressed Physiology: Military Relevance. Nutrients 11(8)doi: 10.3390/nu11081703.

Cooper, K.H. 1968. A means of assessing maximal oxygen intake. Correlation between field and treadmill testing. JAMA 203(3): 201-204.

Crabtree, D.R. and Blannin, A.K. 2015. Effects of exercise in the cold on Ghrelin, PYY, and food intake in overweight adults. Medicine and science in sports and exercise 47(1): 49-57 doi: 10.1249/MSS.0000000000000391.

Dalton, M. and Finlayson, G. 2014. Psychobiological examination of liking and wanting for fat and sweet taste in trait binge eating females. Physiol Behav 136: 128-134 doi: 10.1016/j.physbeh.2014.03.019.

Day, D., Young, A. and Askew, E.W. 2012. Nutrition and military

performance. In Military Quantitative Physiology: Problems and Concepts in Military Operational Medicine. e. K Friedl and WR Santee, Fort Detrick, MD: Office of the Surgeon General, Borden Institute.

DeLany, J.P., Schoeller, D.A., Hoyt, R.W., Askew, E.W. and Sharp, M.A. 1989. Field use of D2 180 to measure energy expenditure of soldiers at different energy intakes. J Appl Physiol (1985) 67(5): 1922-1929 doi: 10.1152/jappl.1989.67.5.1922.

Drenowatz, C. 2015. Reciprocal Compensation to Changes in Dietary Intake and Energy Expenditure within the Concept of Energy Balance. Advances in Nutrition: An International Review Journal 6(5): 592-599 doi: 10.3945/an.115.008615. 
Durnin, J.V. and Womersley, J. 1974. Body fat assessed from total body density and its estimation from skinfold thickness: measurements on 481 men and women aged from 16 to 72 years. Br J Nutr 32(1): 77-97.

Edwards, J.S. and Roberts, D.E. 1991. The influence of a calorie supplement on the consumption of the meal, ready-to-eat in a cold environment. Mil Med 156(9): 466-471. Edwards, J.S.A., Roberts, D.E. and Mutter, S.H. 1992. Rations for use in a cold environment. J Wild Med 3: 27-47.

Engell, D. 1988. Interdependency of food and water intake in humans. Appetite 10(2): 133141 doi: $10.1016 / 0195-6663(88) 90064-5$.

Finlayson, G., Bryant, E., Blundell, J.E. and King, N.A. 2009. Acute compensatory eating following exercise is associated with implicit hedonic wanting for food. Physiol Behav 97(1): 62-67 doi: 10.1016/j.physbeh.2009.02.002.

Finlayson, G., Caudwell, P., Gibbons, C., Hopkins, M., King, N. and Blundell, J. 2011. Low fat loss response after medium-term supervised exercise in obese is associated with exercise-induced increase in food reward. J Obes 2011doi: 10.1155/2011/615624. Finlayson, G., King, N. and Blundell, J. 2008. The role of implicit wanting in relation to explicit liking and wanting for food: implications for appetite control. Appetite 50(1): 120-127 doi: 10.1016/j.appet.2007.06.007.

Finlayson, G., King, N. and Blundell, J.E. 2007. Is it possible to dissociate 'liking' and 'wanting' for foods in humans? A novel experimental procedure. Physiol Behav 90(1): 36-42 doi: 10.1016/j.physbeh.2006.08.020.

Grant, S., Corbett, K., Amjad, A.M., Wilson, J. and Aitchison, T. 1995. A comparison of methods of predicting maximum oxygen uptake. Br J Sports Med 29(3): 147-152.

Holt, G.M., Owen, L.J., Till, S., Cheng, Y., Grant, V.A., Harden, C.J., et al. 2017. Systematic literature review shows that appetite rating does not predict energy intake. Crit Rev Food Sci Nutr 57(16): 3577-3582 doi: 10.1080/10408398.2016.1246414.

Hoyt, R.W., Buller, M.J., DeLany, J.P., Stulz, D., Warren, K., Hamlet, M.P., et al. 2001. Warfighter Physiological Status Monitoring (WPSM): Energy Balance And Thermal Status 
During A 10-Day Cold Weather U.S. Marine Corps Infantry Officer Course Field Exercise. U

523

524

525

526

527

528

\section{S Army Reasearch Institute of Environmental Medicine Technical Report.}

Johnson, C.D., Simonson, A.J., Darnell, M.E., DeLany, J.P., Wohleber, M.F. and Connaboy, C. 2017. Energy expenditure and intake during Special Operations Forces field training in a jungle and glacial environment. Appl Physiol Nutr Metabdoi: 10.1139/apnm-2017-0622. Jones, P.J., Jacobs, I., Morris, A. and Ducharme, M.B. 1993. Adequacy of food rations in soldiers during an arctic exercise measured by doubly labeled water. J Appl Physiol (1985) 75(4): 1790-1797 doi: 10.1152/jappl.1993.75.4.1790.

Karl, J.P., Margolis, L.M., Madslien, E.H., Murphy, N.E., Castellani, J.W., Gundersen, Y., et al. 2017. Changes in intestinal microbiota composition and metabolism coincide with increased intestinal permeability in young adults under prolonged physiological stress. Am J Physiol Gastrointest Liver Physiol 312(6): G559-G571 doi: 10.1152/ajpgi.00066.2017. Karl, J.P., Thompson, L.A., Niro, P.J., Margolis, L.M., McClung, J.P., Cao, J.J., et al. 2015. Transient decrements in mood during energy deficit are independent of dietary protein-tocarbohydrate ratio. Physiol Behav 139: 524-531 doi: 10.1016/j.physbeh.2014.11.068.

King, N., Mutter, S.H., Roberts, D.E., Askew, E.W., Young, A., Jones, T.E., et al. 1992. Nutrition and hydration status of soldiers consuming the 18-man arctic tray pack ration module with either the meal, ready-to-eat or the long life ration packet during a cold weather field training exercise. Natick, MA: United States Army Research Institute of Environmental Medicine Technical Report No T4-92.

King, N., Mutter, S.H., Roberts, D.E., Sutherland, M.R. and Askew, E.W. 1993. Cold weather field evaluation of the 18-Man Arctic Tray Pack Ration Module, the meal, ready-to-eat, and the Long Life Ration Packet. Mil Med 158(7): 458-465.

Kyrolainen, H., Karinkanta, J., Santtila, M., Koski, H., Mantysaari, M. and Pullinen, T. 2008. Hormonal responses during a prolonged military field exercise with variable exercise intensity. Eur J Appl Physiol 102(5): 539-546 doi: 10.1007/s00421-007-0619-0. 
Landry, G.J., Falck, R.S., Beets, M.W. and Liu-Ambrose, T. 2015. Measuring physical activity in older adults: calibrating cut-points for the MotionWatch 8((c)). Front Aging Neurosci 7: 165 doi: 10.3389/fnagi.2015.00165.

Loucks, A.B. 2004. Energy balance and body composition in sports and exercise. J Sports Sci 22(1): 1-14 doi: 10.1080/0264041031000140518.

Mandic, I., Ahmed, M., Rhind, S., Goodman, L., L'Abbe, M. and Jacobs, I. 2019. The effects of exercise and ambient temperature on dietary intake, appetite sensation, and appetite regulating hormone concentrations. Nutr Metab (Lond) 16: 29 doi: 10.1186/s12986-0190348-5.

Margolis, L.M., Murphy, N.E., Martini, S., Gundersen, Y., Castellani, J.W., Karl, J.P., et al. 2016. Effects of Supplemental Energy on Protein Balance during 4-d Arctic Military Training. Med Sci Sports Exerc 48(8): 1604-1612 doi: 10.1249/MSS.0000000000000944.

Mattes, R.D. 2010. Hunger and thirst: issues in measurement and prediction of eating and drinking. Physiol Behav 100(1): 22-32 doi: 10.1016/j.physbeh.2009.12.026.

Mayer, J., Roy, P. and Mitra, K.P. 1956. Relation between caloric intake, body weight, and physical work: studies in an industrial male population in West Bengal. Am J Clin Nutr 4(2): 169-175 doi: 10.1093/ajcn/4.2.169.

McAdam, J., McGinnis, K., Ory, R., Young, K., Fruge, A.D., Roberts, M., et al. 2018.

Estimation of energy balance and training volume during Army Initial Entry Training. J Int Soc Sports Nutr 15(1): 55 doi: 10.1186/s12970-018-0262-7.

Mifflin, M.D., St Jeor, S.T., Hill, L.A., Scott, B.J., Daugherty, S.A. and Koh, Y.O. 1990. A new predictive equation for resting energy expenditure in healthy individuals. Am J Clin Nutr 51(2): 241-247 doi: 10.1093/ajcn/51.2.241.

Morgan, T.E., Hodgess, L.A., Schilling, D., Hoyt, R.W., Iwanyk, E.J., McAninch, G., et al. 1988. A Comparison of the Meal, Ready-To-Eat, Ration, Cold Weather, and Ration, Lightweight Nutrient Intakes During Moderate Altitude cold Weather Field Training Operations. U S Army Reasearch Institute of Environmental Medicine Technical Report T589. 
576 Murphy, N.E., Carrigan, C.T., Philip Karl, J., Pasiakos, S.M. and Margolis, L.M. 2018.

577 Threshold of Energy Deficit and Lower-Body Performance Declines in Military Personnel: A Meta-Regression. Sports Med 48(9): 2169-2178 doi: 10.1007/s40279-018-0945-x. Organization., N.A.T. 2010. Nutrition Science and Food Standards for Military Operations (TR-HFM-154). Neuilly-sur-Seine Cedex: North Atlantic Treaty Organization.

581

582

583

584

585

586

587

588

589

590

591

592

593

594

595

596

597

598

599

600

601

Richmond, V.L., Horner, F.E., Wilkinson, D.M., Rayson, M.P., Wright, A. and Izard, R. 2014.

Energy balance and physical demands during an 8-week arduous military training course. Mil Med 179(4): 421-427 doi: 10.7205/MILMED-D-13-00313.

Riou, M.E., Jomphe-Tremblay, S., Lamothe, G., Stacey, D., Szczotka, A. and Doucet, E. 2015. Predictors of Energy Compensation during Exercise Interventions: A Systematic Review. Nutrients 7(5): 3677-3704 doi: 10.3390/nu7053677.

Rodriguez-Sanchez, N. and Galloway, S.D. 2015. Errors in dual energy x-ray absorptiometry estimation of body composition induced by hypohydration. Int J Sport Nutr Exerc Metab 25(1): 60-68 doi: 10.1123/ijsnem.2014-0067.

Sadoul, B.C., Schuring, E.A., Mela, D.J. and Peters, H.P. 2014. The relationship between appetite scores and subsequent energy intake: an analysis based on 23 randomized controlled studies. Appetite 83: 153-159 doi: 10.1016/j.appet.2014.08.016.

Sirichana, W., Dolezal, B.A., Neufeld, E.V., Wang, X. and Cooper, C.B. 2017. Wrist-worn triaxial accelerometry predicts the energy expenditure of non-vigorous daily physical activities. J Sci Med Sport 20(8): 761-765 doi: 10.1016/j.jsams.2017.01.233.

Tassone, E.C. and Baker, B.A. 2017. Body weight and body composition changes during military training and deployment involving the use of combat rations: a systematic literature review. Br J Nutr 117(6): 897-910 doi: 10.1017/S0007114517000630.

Tharion, W.J., Lieberman, H.R., Montain, S.J., Young, A.J., Baker-Fulco, C.J., Delany, J.P., et al. 2005. Energy requirements of military personnel. Appetite 44(1): 47-65 doi: 10.1016/j.appet.2003.11.010. 
602 Thurber, C., Dugas, L.R., Ocobock, C., Carlson, B., Speakman, J.R. and Pontzer, H. 2019. 603 Extreme events reveal an alimentary limit on sustained maximal human energy expenditure. 604 Sci Adv 5(6): eaaw0341 doi: 10.1126/sciadv.aaw0341.

605 Ward, D.S., Evenson, K.R., Vaughn, A., Rodgers, A.B. and Troiano, R.P. 2005.

606 Accelerometer use in physical activity: best practices and research recommendations. Med 607 Sci Sports Exerc 37(11 Suppl): S582-588.

608 Wasse, L.K., King, J.A., Stensel, D.J. and Sunderland, C. 2013. Effect of ambient 609 temperature during acute aerobic exercise on short-term appetite, energy intake, and plasma 610 acylated ghrelin in recreationally active males. Applied Physiology, Nutrition, and Metabolism 611 38(8): 905-909 doi: 10.1139/apnm-2013-0008.

612 White, L.J., Dressendorfer, R.H., Holland, E., McCoy, S.C. and Ferguson, M.A. 2005.

613 Increased caloric intake soon after exercise in cold water. International journal of sport 614 nutrition and exercise metabolism 15(1): 38-47.

615 Whybrow, S., Hughes, D.A., Ritz, P., Johnstone, A.M., Horgan, G.W., King, N., et al. 2008.

616 The effect of an incremental increase in exercise on appetite, eating behaviour and energy

617 balance in lean men and women feeding ad libitum. Br J Nutr 100(5): 1109-1115 doi:

$618 \quad 10.1017 / S 0007114508968240$. 
619 Table 1. Individual and mean participant characteristics (Means \pm SD)

\begin{tabular}{|c|c|c|c|c|c|c|}
\hline $\begin{array}{c}\# \\
\text { participant }\end{array}$ & Age (y) & Height $(\mathrm{cm})$ & $\begin{array}{c}\text { Body mass } \\
\text { (kg) }\end{array}$ & $\begin{array}{c}\text { Body fat } \\
\text { mass (\% of } \\
\text { body } \\
\text { mass) }\end{array}$ & $\begin{array}{l}\text { Estimated } \\
\text { VO }_{2 \max } \\
\left(\mathrm{ml} . \mathrm{min}^{-}\right. \\
\left.{ }^{1} \cdot \mathrm{kg}^{-1}\right)\end{array}$ & $\begin{array}{c}\text { Physical } \\
\text { activity } \\
\text { volume } \\
\left(\text { h.w } \text { w }^{-1}\right)\end{array}$ \\
\hline 1 & 30 & 173 & 77.0 & 23.0 & 60 & 3 \\
\hline 2 & 29 & 183 & 78.1 & 13.9 & 60 & 3 \\
\hline 3 & 24 & 177 & 86.5 & 22.6 & 60 & 7 \\
\hline 4 & 26 & 173 & 78.0 & 20.9 & 64 & 7 \\
\hline 5 & 29 & 180 & 81.5 & 18.6 & 61 & 10 \\
\hline 6 & 35 & 177 & 72.0 & 25.1 & 59 & 15 \\
\hline 7 & 32 & 178 & 74.8 & 20.9 & 58 & 10 \\
\hline 8 & 30 & 173 & 73.4 & 21.6 & 62 & 10 \\
\hline 9 & 32 & 181 & 78.3 & 19.9 & 58 & 30 \\
\hline 10 & 31 & 186 & 83.5 & 20.7 & 58 & 10 \\
\hline 11 & 45 & 173 & 69.0 & 20.5 & 61 & 20 \\
\hline 12 & 33 & 163 & 60.9 & 21.1 & 75 & 13 \\
\hline Mean \pm SD & $31.3 \pm 5.2$ & $176.4 \pm 6.0$ & $76.1 \pm 6.8$ & $20.7 \pm 2.7$ & $61.5 \pm 4.6$ & $11.5 \pm 7.5$ \\
\hline
\end{tabular}

620 
621 Table 2. Absolute and relative macronutrient intake

\begin{tabular}{|c|c|c|c|}
\hline & Days 1-7 & Days 8-14 & Mean Raid \\
\hline CHO intake (g.d-1) & $314 \pm 49$ & $370 \pm 64^{* *}$ & $342 \pm 50$ \\
\hline CHO intake ( $\%$ of TEI) & $43.3 \pm 7.3$ & $43.5 \pm 6.0$ & $43.4 \pm 6.6$ \\
\hline Fat intake $\left(\mathbf{g} \cdot \mathrm{d}^{-1}\right)$ & $151 \pm 47$ & $175 \pm 59^{* *}$ & $163 \pm 51$ \\
\hline Fat intake ( $\%$ of TEI) & $44.1 \pm 5.9$ & $43.7 \pm 5.4$ & $43.9 \pm 5.6$ \\
\hline Protein intake $\left(g \cdot d^{-1}\right)$ & $93 \pm 34$ & $110 \pm 39^{* *}$ & $102 \pm 36$ \\
\hline Protein intake ( $\%$ of TEI) & $12.1 \pm 2.2$ & $12.3 \pm 1.8$ & $12.2 \pm 1.9$ \\
\hline
\end{tabular}

622

Means \pm SD. ${ }^{* *}$ different from D1-7; $p<0.01$. 
Table 3. Explicit liking and food preference

\section{Day 0 \\ Day 1 \\ Day 10}

\section{Explicit liking}

\begin{tabular}{llll}
\hline High-fat (HF) & $4.4 \pm 1.7$ & $5.0 \pm 1.3$ & $4.6 \pm 1.3$ \\
Low-fat (LF) & $5.0 \pm 1.9$ & $5.4 \pm 1.5$ & $5.8 \pm 1.5$ \\
Sweet (SW) & $4.6 \pm 1.8$ & $4.8 \pm 1.6$ & $5.1 \pm 1.6$ \\
Savory (SA) & $4.9 \pm 1.6$ & $5.6 \pm 1.1$ & $5.3 \pm 1.0$ \\
High-fat and sweet (HFSW) & $4.1 \pm 2.4$ & $4.3 \pm 1.7$ & $4.3 \pm 2.0$ \\
High-fat and savory (HFSA) & $4.7 \pm 1.6$ & $5.7 \pm 1.2$ & $4.9 \pm 1.4$ \\
Low-fat and sweet (LFSW) & $5.0 \pm 2.2$ & $5.3 \pm 2.1$ & $5.9 \pm 2.1$ \\
Low-fat and savory (LFSA) & $5.0 \pm 1.8$ & $5.5 \pm 1.5$ & $5.7 \pm 1.1$ \\
\hline
\end{tabular}

\section{Food preference}

\begin{tabular}{llll}
\hline HF minus LF & $-1.0 \pm 4.9$ & $-1.2 \pm 4.2$ & $-3.7 \pm 3.7$ \\
HFSW minus LFSW & $-0.3 \pm 4.2$ & $-1.8 \pm 2.8$ & $-2.8 \pm 3.5$ \\
HFSA minus LFSA & $-0.8 \pm 1.5$ & $0.7 \pm 2.2$ & $-0.9 \pm 1.4$ \\
SW minus SA & $-1.8 \pm 6.5$ & $-3.3 \pm 5.3$ & $-0.5 \pm 5.1$ \\
HFSW minus HFSA & $-0.7 \pm 3.8$ & $-2.9 \pm 2.6$ & $-1.2 \pm 3.4$ \\
LFSW minus LFSA & $-1.2 \pm 3.7$ & $-0.4 \pm 3.3$ & $0.7 \pm 3.0$
\end{tabular}

624 Means \pm SD. Explicit liking is scored from 0 to 10 using a VAS. Food preference was based

625 on the $\mathrm{FPQ}-\mathrm{S}_{16}$ : scores in each category were subtracted to obtain a bias score comparing 626 two categories, with a negative score indicating that food preference is higher in the latter 627 than the former category. 
Table 4 - Correlation table

\begin{tabular}{|c|c|c|c|}
\hline Variables & $r$ & Variables & $r$ \\
\hline$\Delta$ Body mass (\%) & & EI D1-7 (kcal.d-1 $)$ & \\
\hline vs Mean El $\left(k^{\left.2 c a l . d^{-1}\right)}\right.$ & $0.656^{*}$ & vs Hunger D1-7 (cm) & $0.743^{* *}$ \\
\hline vs Mean EE $\left(\mathrm{kcal}^{\mathrm{d}} \mathrm{d}^{-1}\right)$ & -0.402 & vs Hunger D8-14 $(\mathrm{cm})$ & 0.340 \\
\hline vs Mean EB (kcal. $\left.\mathrm{d}^{-1}\right)$ & $0.702^{*}$ & vs Mean Hunger (cm) & $0.707^{*}$ \\
\hline vs Mean $\mathrm{CHO}$ intake $\left(\mathrm{kcal}^{\left.-\mathrm{d}^{-1}\right)}\right.$ & -0.219 & EI D8-14 (kcal.d-1 $)$ & \\
\hline vs Mean fat intake $\left(\mathrm{kcal} . \mathrm{d}^{-1}\right)$ & $0.780^{\star *}$ & vs Hunger D1-7 (cm) & 0.252 \\
\hline vs Mean protein intake $\left(\mathrm{kcal} . \mathrm{d}^{-1}\right)$ & $0.656^{*}$ & vs Hunger D8-14 (cm) & $0.652^{*}$ \\
\hline vs Mean $\mathrm{CHO}$ intake (\% of $\mathrm{El}$ ) & $-0.795^{\star *}$ & vs Mean Hunger (cm) & $0.617^{*}$ \\
\hline vs Mean fat intake (\% of El) & $0.765^{\star *}$ & Mean El $\left(\mathrm{kcal} . \mathrm{d}^{-1}\right)$ & \\
\hline vs Mean protein intake (\% of El) & 0.544 & vs Hunger D1-7 (cm) & 0.471 \\
\hline vs EL HFSW D0 (cm) & 0.098 & vs Hunger D8-14 (cm) & 0.563 \\
\hline vs EL HFSW D1 (cm) & 0.564 & vs Mean Hunger $(\mathrm{cm})$ & $0.692^{*}$ \\
\hline vs EL HFSW D10 (cm) & $0.600^{*}$ & vs EL HF D10 (cm) & $0.646^{*}$ \\
\hline \multicolumn{4}{|l|}{$\Delta$ Body fat mass (\%) } \\
\hline vs EL HF D0 (cm) & 0.232 & & \\
\hline vs EL HF D1 (cm) & $0.706^{* *}$ & & \\
\hline vs EL HF D10 (cm) & $0.680^{*}$ & & \\
\hline \multicolumn{4}{|c|}{ 'Mean' indicates the average value for the 14 days. Otherwise, the period is indicated (e } \\
\hline \multicolumn{4}{|c|}{ D1-7). Significant correlations between two variables are highlighted in bold. ${ }^{*} p<0.05 ;{ }^{* *} p$} \\
\hline 0.01. El: energy intake; EE: & expe & e; EB: energy bala & bohy \\
\hline
\end{tabular}




\section{Figure legends}

634

635

636

637

638

639

640

641

642

643

644

645

Figure 1. Details of the route of the expedition and meteorological conditions. Open circles indicate that they remained in the same location on the specific day.

Figure 2. Daily (A, C, and E) energy intake, expenditure, and balance and their means (B, D and F) for each half of the expedition. The doted lines indicate the mean value for the entire expedition. ${ }^{*, * *}$ different from D1-7; ${ }^{*} p<0.05,{ }^{* *} p<0.01 .{ }^{\alpha \alpha}$ different from EE, $p<$ 0.01

Figure 3. Individual (A) and mean (B) body mass and body composition and comparison between individual body mass and changes in energy balance (C). ${ }^{* * *}$ different from before the expedition; $p<0.001$.

Figure 4. Daily ( $A$ and $C$ ) morning and evening hunger scores and their means ( $B$ and D) for each half of the expedition. The doted lines indicate the mean value over the entire expedition. 

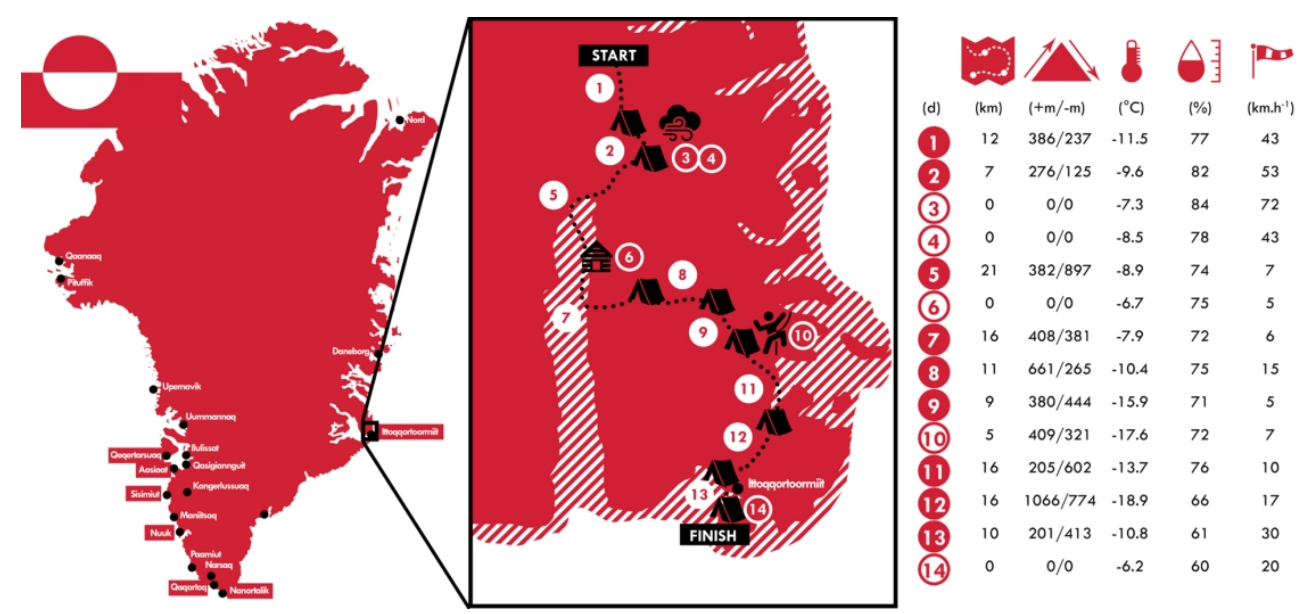

Figure 1. Details of the route of the expedition and meteorological conditions. Open circles indicate that they remained in the same location on the specific day. 

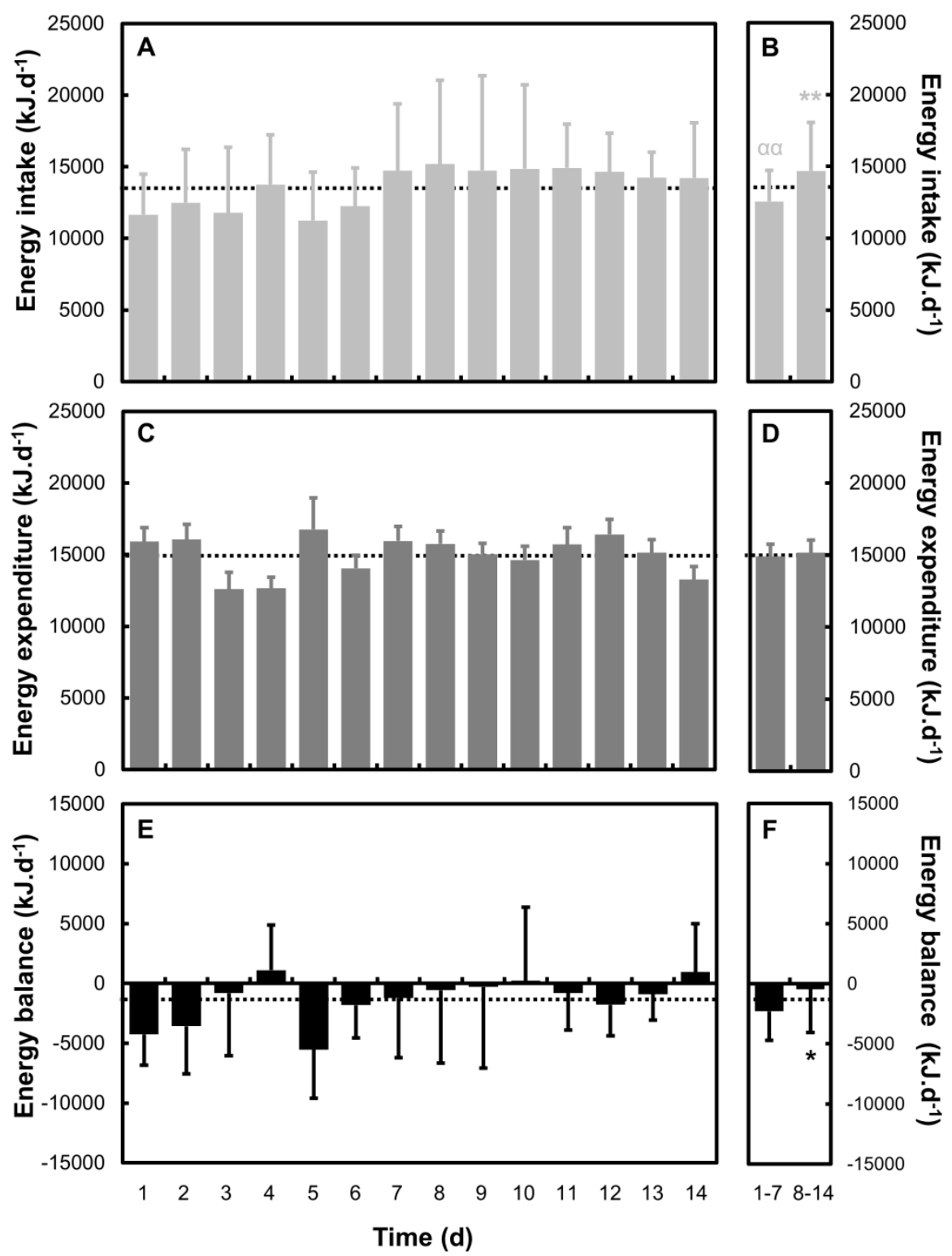

Figure 2. Daily ( $A, C$, and $E$ ) energy intake, expenditure, and balance and their means ( $B, D$ and $F)$ for each half of the expedition. The doted lines indicate the mean value for the entire expedition. $* * *$ different from $\mathrm{D} 1-7 ; * \mathrm{p}<0.05, * * \mathrm{p}<0.01$. aadifferent from EE, $\mathrm{p}<0.01$.

$190 \times 240 \mathrm{~mm}(325 \times 325 \mathrm{DPI})$ 

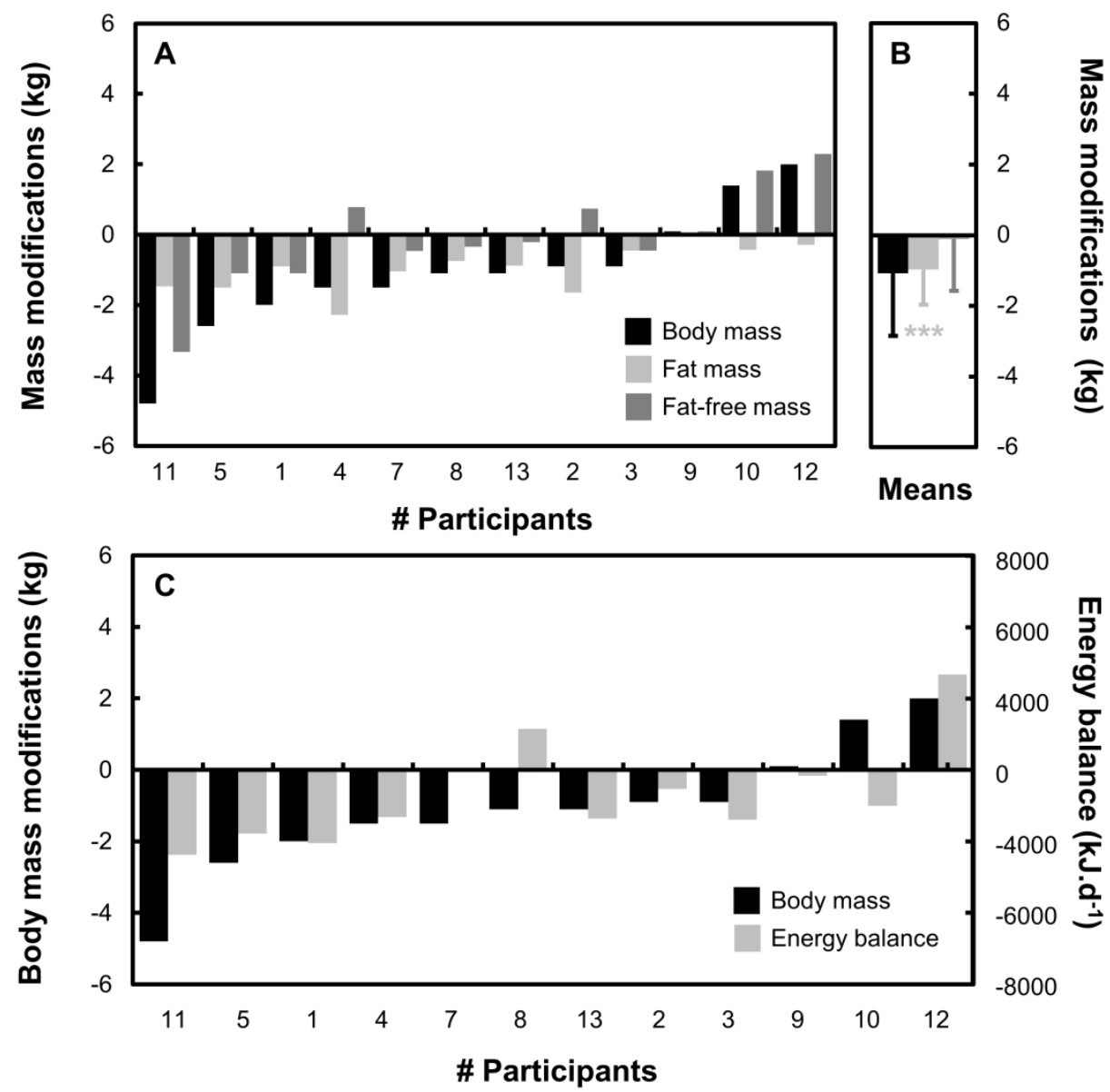

Figure 3. Individual $(A)$ and mean (B) body mass and body composition and comparison between individual body mass and changes in energy balance $(C)$. ***different from before the expedition; $p<0.001$.

$190 \times 179 \mathrm{~mm}(410 \times 410 \mathrm{DPI})$ 


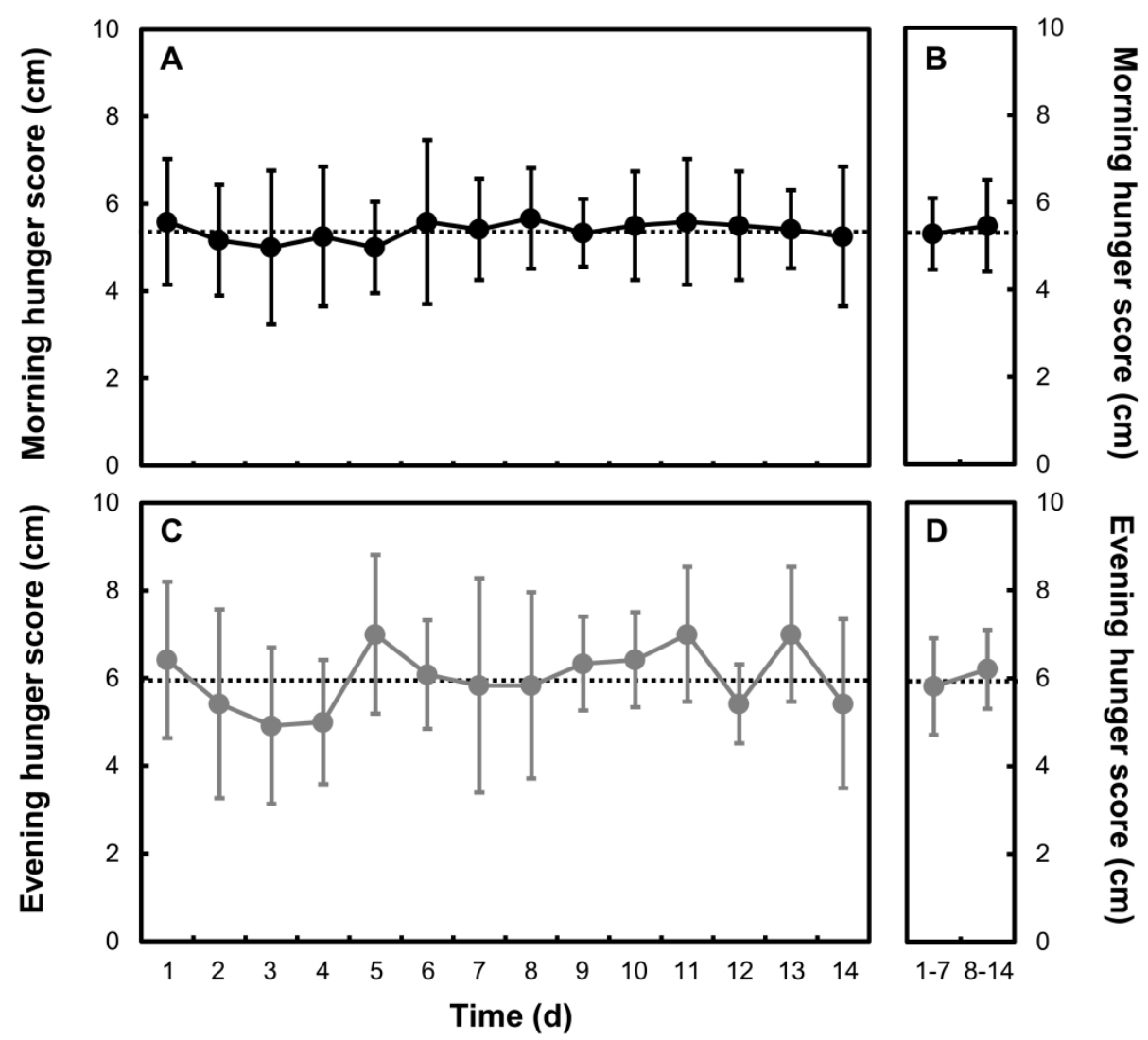

Figure 4. Daily ( $A$ and $C$ ) morning and evening hunger scores and their means ( $B$ and $D$ ) for each half of the expedition. The doted lines indicate the mean value over the entire expedition.

$190 \times 169 \mathrm{~mm}(410 \times 410 \mathrm{DPI})$ 